\title{
Evaluating the Methods for Postvoiding Residual Volume Assesment and Factors That May Influence the Results
}

\author{
İşeme Sonrası Rezidü İdrar Hacminin Ölçümünde Kullanılan Yöntemlerin \\ Karşılaştırılması ve Bunlar Üzerine Etkili Olabilecek Parametrelerin \\ Değerlendirilmesi
}

\author{
Ünal Bıçakçı \\ Ondokuz Mayıs University, Department of Paediatric Surgery and Division of Paediatric Urology, Samsun, Turkey
}

öz

Amaç: Işeme sonrası rezidü (ISR) alt üriner semptomlarının değerlendirilmesinin parçasıdır. ISR; üretralkateterizasyon ve Ultrason (USG) ile belirlenir. USG, invazif olmayan bir yöntemdir. iSR'nin ölçümünde kullanılan metodları ve etkileyebilecek faktörleri değerlendirdik.

Hastalar ve Metod: Otuziki hasta değerlendirildi; 18 spinabifidalı (SB grubu) (10 kız, 8 erkek: ortalama $6.2 \pm 0.83 \mathrm{yıl}$ ) ve 14 aşırı aktif mesane tanısı (AAM grubu) (5 kız, 9 erkek:ortalama $7.4 \pm 0.6$ yıl)

iSR'nin ölçümünde, Üretralkateterizsayon, Caresono ${ }^{\circledR}$ PadScan HD 5 USG ve miksiyonsistoüretrogram (MCUG) teknikleri kullanıldı. Vezikoüreteralreflü (VUR), renalskar ve mesane trabekülasyon mevcudiyeti araştırıldı.

Bulgular: SB grubunda katater iSR; $144.4 \pm 40.7 \mathrm{ml}$ veAAM grubunda katater ISR; $60.7 \pm 18.4 \mathrm{ml}(p>0.05)$. SB grubunda USG ISR $146.2 \pm 41.2$ mlve AAM grubunda USG ISR $60.6 \pm 20.4 \mathrm{ml}$ (p>0.05). SB grubunda MCUG iSR $100 \pm 27.1 \mathrm{ml}$ veAAM grubunda MCUG ISR $25.4 \pm 8.7 \mathrm{ml}$ 'dir $(\mathbf{p}>0.05)$. AAM grubunda iSR açısından katater ile USG korelasyon katsayısı ( $r$ değeri); 0.96 ( $\mathbf{p}<0.01)$, katater ile MCUG $r$ değeri; $0.58(p<0.05)$ ve USG ile MCUG $r$ değeri; 0.486 ( $p>0.05)$. SB grubunda iSR açısından katater ile USG korelasyon katsayısı ( $r$ değeri); 0.948 ( $\mathbf{p}<0.01)$, katater ile MCUG $r$ değeri; $0.540(\mathbf{p}<0.05)$ ve USG ile MCUG $r$ değeri;0.018( $p<0.05)$. Böbrek skar mevcudiyetinin, ISR değerleri üzerine etkisi bulunamadı ( $p>0.05$ ).VUR ile iSR arasında istatistiksel anlamlılık bulunamadı. VUR ile her iki gruptaki iSR açııından korelasyon katsayılarında anlamlılık yoktu ( $p>0.05$ ). Mesane trabekülasyonu açısından AAM ve SB gruplarındafark bulunmadı $(P>0.05)$

Sonuç: Ultrason ile rezidü ölçümü üretralkataterizasyon kadar doğru sonuç vermektedir. Miksiyonsistoüretrogram ile rezidü ölçümü en az güvenilir metoddur.

Anahtar Kelimeler: Plazminojenaktivatör inhibitor-1, papillertiroid kanseri, ürokinazplazminojenaktivatörü
ABSTRACT

Aim: Postvoiding residual (PVR) urine is measured by urethral catheterization (UC), portable ultrasonography (USG) or voiding cystourethrogram (VCUG) images. We evaluated those three different PVR assessment methods and parameters that may interfere with the results.

Patients and Methods: Eighteen patients with spinal bifida (SB) (10 female and 8 male, mean $6.2 \pm 0.83$ years old) (Group I) Fourteen patients with lower urinary tract symptoms (LUTS) (5 female and 9 male, mean 7.4 \pm 0.6 )(Group II). PVR measurements were performed by urethral catheterization (UC), portable Caresono PadScan HD $5^{\circ}$ USG and on voiding cystourethrogram (VCUG) images. Relation with vesicourethral reflux (VUR), renal scaring (on DMSA), bladder trabeculation (BT) is evaluated.

Results: Mean PVR volumes approximately same in the catheter and ultrasound groups ( $p>0.05$ ). PVR is less in the VCUG grup when compare other groups but statistically not significant $(p>0.05)$. Significant correlation between catheter PVR and USG PVR group $(p<0.01, r: 0.94$ and $r: 0.96)$. Although no significant difference is demonstrated for VUR in both groups $(p>0.05)$, PVR values are higher in patients with higher VUR degrees. There was no statistical difference according to existing of scaring in both groups ( $p>0.05)$. There was no statistical difference according to existing bladder trabeculation in both groups ( $p>0.05)$

Conclusion: Measurement of PVR by portable ultrasonography yields comparable results with urethral catheterization. Although PVR measurement on VCUG images is a less reliable method, it can provide additional information in certain conditions (ie. VUR, diverticulum..). Although statistical significance could not be demonstrated, we believe that VUR, renal scaring and bladder trabeculation may interfere with the results of PVR assessments.

Keywords: Postvoiding residual volume, Portable ultrasound, Urethral catheterization, children 


\section{Introduction}

The postvoid residual volume (PVR) is defined as the quantity of urine left in the bladder after voiding (1). The PVR is essential component in the assessment of patients with lower urinary tract symptoms (LUTS) or neuropathic bladder (2). Urethral catheterization (UC) is reliable and standard method for measurement of PVR. But it has disadvantages such as; being invasive, comfortless and risk of urinary tract infection (3). Portable bladder scanner (PBS) is noninvasive and alternative method for PVR measurement $(4,5)$. But reliability of PBS in children is not proven. We aimed correlate UC, PBS and VCUG residual volume and assess the factors may effect the results.

\section{Material and Methods}

Group I; Eighteen patients with spina bifida (SB) (10 female and 8 male, mean $6.2 \pm 0.83$ years old)

Group II; Fourteen patients with lower urinary tract symptoms (LUTS) (5 female and 9 male, mean $7.4 \pm 0.6$ years old).

PVR measurements were performed by urethral catheterization (UC), portable Caresono PadScan HD $5^{\circ}$ USG and on voiding cystourethrogram (VCUG) images.
We evaluated the effects of vesicoureteral reflux (VUR), renal scaring (on DMSA), bladder trabeculation (BT) parameters on PVR results.

\section{Results}

Mean PVR volumes in the groups with each method ( $p>0.05$ ) are shown in Table 1.

Significant correlation between catheter PVR and USG PVR group ( $p<0.01, r: 0.94$ and r:0.96) (Table 2).

Although no significant difference is demonstrated for VUR in the groups $(p>0.05)$, PVR values are higher in patients with higher VUR degrees (Table 3 ).

There was no statistical difference according to existing of scaring in the groups ( $p>0.05$ ) (Table 4 ).

There was no statistical difference according to existing bladder trabeculation in the groups ( $p>0.05$ ) (Table 5).

Table 1: SB: Spinal bifid, OAB; Overactive bladder, PVR: Postvoiding residual volume

\begin{tabular}{|l|l|l|l|}
\hline PVR (ml) & Catheter & USG & VCUG \\
\hline SB & $144 \pm 40.7$ & $146.2 \pm 41.2$ & $100 \pm 27.1$ \\
\hline OAB & $60.7 \pm 18.4$ & $60.6 \pm 20.4$ & $25.4 \pm 8.7$ \\
\hline
\end{tabular}

Table 2: Correlation analysis is shown. $r=$ Correlation coefficient

\begin{tabular}{|l|l|l|l|}
\hline & Catheter\& USG & Catheter \&VCUG & USG\&VCUG \\
\hline SB & $r: 0.948 p<0.01$ & $r: 0.540<0.05$ & $r: 0.549 p<0.05$ \\
\hline OAB & $r: 0.96 p<0.01$ & $r: 0.58 p<0.05$ & $r: 0.486 p>0.05$ \\
\hline
\end{tabular}

Table 3: Manipulations compared to VUR evaluations is shown.

\begin{tabular}{|l|l|l|l|l|l|l|}
\hline PVR (ml) & Catheter\& VUR (+) & USG \& VUR (+) & VCUG\& VUR (+) & Catheter \& VUR (-) & USG \& VUR (-) & VCUG\& VUR (-) \\
\hline SB & $194.8 \pm 90.5$ & $178.5 \pm 94.2$ & $131.4 \pm 62.9$ & $112.3 \pm 34.9$ & $126.8 \pm 35$ & $80 \pm 20.8$ \\
\hline OAB & $75.4 \pm 29.2$ & $74.5 \pm 30.7$ & $23.5 \pm 14.0$ & $46.0 \pm 23.5$ & $46.7 \pm 28.4$ & $27.1 \pm 11.2$ \\
\hline
\end{tabular}

VUR: Vesicoureteral reflux 
Table 4: Residue according to scar formation.

\begin{tabular}{|l|l|l|l|l|l|l|}
\hline PVR (ml) & Catheter\& Scar (+) & USG\& Scar (+) & VCUG\& Scar (+) & Catheter\& Scar (-) & USG\& Scar (-) & VCUG \& Scar (-) \\
\hline SB & $279.2 \pm 121.8$ & $255 \pm 133.2$ & $192 \pm 86.5$ & $92.6 \pm 23.4$ & $104 \pm 22.8$ & $64.6 \pm 10.4$ \\
\hline AAM & $88.6 \pm 31.5$ & $91.5 \pm 36.8$ & $39.3 \pm 14.8$ & $32.8 \pm 15.2$ & $29.7 \pm 11.5$ & $11.4 \pm 7.4$ \\
\hline
\end{tabular}

SB: Spinal bifid, OAB; Overactive bladder

Table 5: Residue measurement compared to trabeculations.

\begin{tabular}{|l|l|l|l|l|l|l|}
\hline PVR (ml) & Catheter\& Trb (+) & USG \& Trb (+) & VCUG\& Trb (+) & Catheter\& Trb (-) & USG \& Trb (-) & MCUG\& Trb (-) \\
\hline SB & $206 \pm 73.9$ & $218 \pm 74.5$ & $138 \pm 50.9$ & $82.2 \pm 27.2$ & $74.3 \pm 19.3$ & $61.1 \pm 12.4$ \\
\hline OAB & $74.2 \pm 27.3$ & $70.8 \pm 36.7$ & $51 \pm 17.6$ & $53.2 \pm 25.2$ & $55 \pm 25.8$ & $11.1 \pm 5.6$ \\
\hline
\end{tabular}

SB: Spinal bifid, OAB; Overactive bladder, Trb.: Trabeculation

\section{Discussion}

The measurement of PVR volume is valuable information in evaluating patients with lower urinary tract symptoms. True PVR measurement provides appropriate management in those patients (6). Urethral catheterization has been considered gold standard for PVR measurement. Although UC is reliable method, it is invasive and cause distress in children. UC has also cause urethral trauma and urinary tract infection (7). Rosseland et all (8) found that the bladder emptying with catheter was in complete in 30 $\%$ of patients and cause wrong measurement of PVR. Huang Stoller ML et all (9) also reported that single catheterization is not sufficient method for PVR and may not make therapeutic decision.

Measurement of PVR by portable USG yields comparable results with urethral catheterization, provides non-invasive method and faster $(10,11)$. In our groups, PVR measurement results is similar between catheter and portable Caresono PadScan HD $5^{\circ}$ USG methods. PVR volume on VCUG images is a less reliable method according to our results. However VCUG can provide additional information in certain conditions (ie.VUR, diverticulum).

We believe that VUR, renal scaring and bladder trabeculation may interfere with the results of PVR assessments, although statistical significance could not be demostrated in our groups.

In conclusion, portable Caresono PadScan HD $5^{\circ}$ USG is as reliable as catheter to measure postvoid residue in paediatric patients with lower urinary tract symptoms or neuropathic bladder. In the future, measurement of PVR with portable USG will take the place of catheter with the less morbidity and more accuracy.

\section{References}

1. Jalbani IK, Ather MH. The accuracy of three-dimensional bladder ultrasonography in determining the residual urinary volume compared with conventional catheterisation. Arab of Urol 2014: 12, 209-213

2. Ghani KR, Pilcher J, Rowland D, Patel U, Nassiri D, Anson K. Portable ultrasonography and bladder volume accuracy- A comparative study using three-dimensional ultrasonography. Urology 2008: 72(1), 24-28

3. Teng $\mathrm{CH}$, Huang $\mathrm{YH}$, Kuo BJ, Bih LI. Application of portable ultrasound scanners in the measurement of post-void residual urine. J of Nursing Research 2005: 13(3), 216-223

4. Rowe J, Price N, Upadhyay V, Evaluation of the bladderscan ${ }^{\circledR}$ in estimating bladder volume in paediatric patients. J Ped Urol 2014: 10, 98-102

5. De Gennaro M, Capitanucci ML, Di Ciommo V, Adorisio O, Mosiello G, Orazi C. 
Reliability of bladder volume measurement with bladderscan in paediatric patients. Scand J Urol Nerphrol 2006: 40, 370-375

6. Uluocak N, Oktar $\mathrm{T}$, Ander $\mathrm{H}$, Ziylan $\mathrm{O}$, Acar O, Rodoplu H, Erkorkmaz U. Which method is the most reliable in determination of bladder capacity in children with idiopathic overactive bladder? A comparison of maximum voided volume, uroflowmetry and maximum cystometric capacity. J Ped Urol 2009: 5, 480-484

7. Abdelwahab HA, Abdalla HM, Sherief $M H$, Ibrahim MB, Shamaa MA. The realiability and reproducibility of ultrasonography for measuring the residual urine volume in men with lower urinary tract symptoms. Arab J of Urol 2014: 12, 265-289

8. Rosseland LA, Bentsen G, Hopp E, Refsum $\mathrm{S}$, Breivik $\mathrm{H}$. Monitoring urinary bladder volume and detecting post-operative urinary retention in children with an ultrasound scanner. Acta Anaesth Scand 2005: 49, 1456-1459

9. Stoller ML, Millard RJ. The accuracy of catheterized residual urine. J Urol 1989: 141(1), 1516

10. Roehrborn CG, Peters PC. Can transabdominal ultrasound estimation of postvoiding residual (PVR) replace catheterization? Urology 1988: 31, 445-449

11. Marks LS, Dorey FJ, Macairan ML, Park C, deKemion JI. Three-dimensional ultrasound device for rapid determination of bladder volume. Urology 1997: 50, 341-348 